\title{
A study on Kudoa septempunctata infection from sashimi and sushi of olive flounder Paralichthys olivaceus in Busan, South Korea
}

\author{
Hee-soo Koo*, Ji-young Park, Gyung-hye Sung, Eun-hee Park, Pyeong-tae Ku, Mi-ok Lee \\ Foodborne Diseases Inspection Team, Busan Metropolitan City Institute of Health \& Environment, Busan, Korea
}

\begin{abstract}
Kudoa septempunctata has been reported as a new parasite in aquacultured olive flounder Paralichthys olivaceus, and also as a causative agent of food poisoning in humans. This paper investigated the infection of K. septempunctata in 216 sashimi and 20 sushi made of olive flounders in Busan, Korea. Among 236 samples, K. septempunctata was detected in eleven sashimi with 6-7 polar capsules by the microscopy. Among eleven sashimi, five sashimi were positive in Polymerase Chain Reaction (PCR) assay with the targets of $18 \mathrm{~S} \mathrm{rDNA}$ and $28 \mathrm{~S}$ rDNA. The genotype of all the five PCR results is identified as the genotype ST3 which is common in Korea. K. septempunctata was found in olive flounders sashimi from Samcheonpo and Wando outside of Jeju Island. These findings would contribute to establish the standard of $K$. septempunctata for preventing food-borne outbreaks in advance and providing further preventive management for the seafood safety.
\end{abstract}

Keywords: Kudoa septempunctata, Food poisoning, Olive flounder, ST3

\section{Introduction}

Kudoa septempunctata has been known to be a parasite on fish muscles, digestive tract and kidneys, and has 6-7 polar cysts per spore, but does not affect fish physiology or survival (Matsukane et al., 2010). Some studies have reported that eating raw fish infected with K. septempunctata causes food poisoning in humans (Ahn et al., 2015; Jang et al., 2016). Kawai et al. (2012) analyzed 113 food poisoning patients in eight prefectures of Japan in 2010 , and reported that the main cause was olive flounders in- fected with K. septempunctata. Since K. septempunctata was also detected in the feces of patients associated with consumption of sliced raw olive flounders, the Ministry of Health, Labor, and Welfare of Japan declared the K. septempunctata as a new causative agent of foodborne disease, and the associated foodborne illness was named Kudoa food poisoning (Harada et al., 2012; Jeon \& Kim, 2016), which has a shorter incubation period of 2-20 hours compared to other food poisoning-causing pathogens (Matsukane et al., 2010). The genotypes of K. septempunctata are classified as three types: ST1, ST2, and ST3. Both ST1

Received: May 11, 2021 Revised: Jul 20, 2021 Accepted: Jul 21, 2021

${ }^{\star}$ Corresponding author: Hee-soo Koo

Foodborne Diseases Inspection Team, Busan Metropolitan City Institute of Health \& Environment, Busan, Korea

Tel: +82-51-309-2883, E-mail: hskoo@korea.kr

This is an Open Access article distributed under the terms of the Creative Commons Attribution Non-Commercial License (http://creativecommons.org/licenses/by$\mathrm{nc} / 4.0 /$ ) which permits unrestricted non-commercial use, distribution, and reproduction in any medium, provided the original work is properly cited.

Copyright $\odot 2021$ The Korean Society of Fisheries and Aquatic Science 
and ST2 were found mainly in Japan, but ST3 is mostly known to be detected in Korea (Takeuchi et al., 2016). Some animal tests using Asian house shrew Suncus murinus found that $10^{7}$ spores of K. septempunctata per $1 \mathrm{~g}$, caused food poisoning symptoms such as vomiting and diarrhea (Kawai et al., 2012; Ohnishi et al., 2013). In the analysis on the residues of the food poisonings, more than $10^{6}$ spores were found out of $1 \mathrm{~g}$ of olive flounders, and this concentration was set as the standard for food poisoning in Japan (Kawai et al., 2012).

So far some studies have been conducted to investigate the infection of K. septempunctata of olive flounders in Korea. Song et al. (2013) collected 143 olive flounders obtained from 26 fish farms in Jeju, and 4 samples out of 143 detected as K. septempunctata positive. Moreover, Song et al. (2014) collected 1,107 olive flounders from 89 fish farms in Jeju, Jeollanam-do, Gyeongnam, Gyeongbuk, and Gangwon-do in Korea, and 0.9\% of the olive flounders in Jeju were only found to be K. septempunctata positive, but $K$. septempunctata were not detected in olive flounders in other regions. K. septempunctata infection was detected in olive flounders exported from Korea to Japan, so the Japanese government tightened quarantine inspection on olive flounders from Jeju in Korea, using $10^{6}$ spores as the judgement standard (Jeon \& Kim, 2016; Kim et al., 2015). As a result, the Ministry of Oceans and Fisheries of Korea has implemented Kudoa management measures for fish farms at the same level as Japan since April 2014. However, the actual concern is the food poisoning caused from eating sliced raw seafood such as sashimi or sushi with $K$. septempunctata infected. Not only in Korea but also in all of the world, the K. septempunctata standard for sashimi or sushi has not been established, which requires the management strategy for preventing the Kudoa food poisoning.

Within the authors' knowledge, the previous studies have focused mainly on $K$. septempunctata infection of olive flounders from fish farms, and there has been no research on $K$. septempunctata-infected sashimi or sushi that people can eat right away. Therefore, this study is to investigate the contamination status of K. septempunctata in sashimi and sushi in Busan, Korea, where eating the raw seafood is traditional food culture, and provide basic data necessary for preventing and managing Kudoa food poisoning.

\section{Materials and Methods}

\section{Test samples}

From January to December in 2020, 236 samples including 216 sashimi and 20 sushi made of olive flounders were collected from seafood markets and sashimi restaurants in Busan. The samples used in the study were purchased from the market by government employees of the Environmental Sanitation Department of 16 district offices in Busan. The samples were refrigerated and transported to the laboratory, and the experiments were conducted immediately.

\section{Sample preprocessing and screening tests}

According to the Korean Food Code, the K. septempunctata infection test in this paper is carried out as follows; (1) scratch the surface of the sashimi and sushi at least five places and obtain 1 g, (2) apply saline solution to it, (3) mash the bottom lightly with a flat surface, (4) centrifuge the solution through the mesh at $1,500 \times \mathrm{g}$ at $4{ }^{\circ} \mathrm{C}$ for 15 minutes, (5) dispose of the top part of the solution and add saline to the sediment and mix it to obtain a homogenized solution as a test solution. DNA was extracted according to the manual of the Fast DNA Spin Kit for Soil (Mpbio, Santa Ana, CA, USA) manufacturer. The extracted DNA was inserted into the PowerCheck ${ }^{\mathrm{TM}}$ Kudoa Real-time PCR Kit (Kogenbiotech, Seoul, Korea) and the Kudoa Screening Test was performed using the Real-time PCR (ABI 7500 Fast, Alameda, CA, USA), which was also followed by the manufacturer's manual.

\section{Microscopic examination}

From the Real-time PCR results, if an amplification appears when the $\mathrm{Ct}$ value is less than 35 , and if the quantitative value is $1.0 \times$ $10^{5}$ or higher, then we carried out a microscopic examination to check the spores of K. septempunctata as follows; (1) add $10 \mathrm{uL}$ trypan blue solution to $10 \mathrm{uL}$ test solution and mix it, (2) inject the obtained $20 \mathrm{uL}$ solution into the hemocytometer, (3) examine the presence of Kudoa spores containing 6 to 7 cysts under a microscope (Carl zeiss, Oberkochen, Germany) and count them.

\section{Genetic identification and genotype analysis}

If the Real-time PCR test results show an amplification curve, then the nested PCR was carried out for detecting K. septempunctata using primers to detect $18 \mathrm{~S}$ rDNA and $28 \mathrm{~S}$ rDNA, according to Grabner et al. (2012) (Table 1). The target size was verified using Automatic Electrophoresis (QIAxcel advanced, Cologne, Germany), and we analyze the sequence obtained from the gene amplification PCR, and confirm whether it is equivalent to the standard strains of NCBI Blast (https://www. ncbi.nlm.nih.gov/Blast).

According to Takeuchi et al. (2015), we performed nested 
Table 1. Primer sequences

\begin{tabular}{|c|c|c|}
\hline Target & Primer & Sequence $\left(5^{\prime}-3^{\prime}\right)$ \\
\hline \multirow[t]{4}{*}{ 18S rDNA } & Ks $18 \mathrm{~S} 1 \mathrm{st}-\mathrm{F}$ & GGTGGGAGCATTTATTAGACT \\
\hline & Ks $18 \mathrm{~S} 1$ st- $\mathrm{R}$ & AATCGAGACCACTGTCAAC \\
\hline & Ks 18S 2nd-F & AGAAATACCGGAGTGGACCGTAAAATG \\
\hline & Ks $18 \mathrm{~S} 2 \mathrm{nd}-\mathrm{R}$ & GTTCCATGCTATAACATTCAAGCGTTCG \\
\hline \multirow[t]{4}{*}{$28 \mathrm{~S}$ rDNA } & Ks $28 \mathrm{~S} 1 \mathrm{st}-\mathrm{F}$ & TGCGTAGTGAAGCGGGAAAA \\
\hline & Ks $28 \mathrm{~S} 1$ st- $\mathrm{R}$ & GTGTTTCAAGACGGGTCGG \\
\hline & Ks 28S 2nd-F & GTGTGTGATCAGACTTGATATG \\
\hline & Ks $28 \mathrm{~S} 2 \mathrm{nd}-\mathrm{R}$ & AAGCCAAAACTGCTGGCCATTT \\
\hline \multirow{4}{*}{$\begin{array}{l}\text { Cytochrome coxidase } \\
\text { subunit } 1\end{array}$} & $\operatorname{cox} 11 \mathrm{st}-\mathrm{F}$ & TTTGTTCATCGGCACAATTC \\
\hline & $\operatorname{cox} 11 \mathrm{st}-\mathrm{R}$ & ATAGCCTGGAACAAGGAATC \\
\hline & $\operatorname{cox} 12 n d-F$ & TATGGCAAAGAAGGTCTGAT \\
\hline & $\operatorname{cox} 12 n d-R$ & TCTAGGGATTCCACAAAGAC \\
\hline \multirow[t]{4}{*}{ Large subunit rRNA } & rnl 1st-F & TGCCGTCAATTCTGTTGTATT \\
\hline & rnl 1st-R & AATACCCATGCTGTGTTCAT \\
\hline & $\mathrm{rnl} 2 \mathrm{nd}-\mathrm{F}$ & GTTCCAACAAGTCCATGAA \\
\hline & $\mathrm{rnl} 2 \mathrm{nd}-\mathrm{R}$ & GACTTTATGGACAACTCAGC \\
\hline
\end{tabular}

PCR for the genotype analysis of $K$. septempunctata under the conditions of $95^{\circ} \mathrm{C}$ for 3 minutes, 35 cycles of $95^{\circ} \mathrm{C}$ for $30 \mathrm{sec}-$ onds, $55^{\circ} \mathrm{C}$ for 30 seconds, $68^{\circ} \mathrm{C}$ for 60 seconds, and $68^{\circ} \mathrm{C}$ for 5 minutes (Table 1). The gene sequence from PCR results is aligned by using the ClustalX BioEdit program, the genotype analysis was carried out by comparing the sequence with the standard strain and the sequence variation at a certain size (Table 2).

\section{Statistics analysis}

For the statistical significance tests, the Chi-square test is conducted using SPSS 22.0 software (IBM, Armonk, NY, USA), which is determined to be statistically significant when the $p$-value is less than 0.05 .

\section{Results and Discussion}

\section{The genotype analysis for detected $K$. septempunctata}

We conducted a Real-time PCR screening test on 236 samples of sashimi and sushi of the olive flounders. In order to perform the quantitative analysis, we made the calibration curve from the five standard reference materials for $1.0 \times 10^{7}, 1.0 \times 10^{5}$, $1.0 \times 10^{4}, 1.0 \times 10^{3}$ Kudoa DNA copy. As shown in Table 3, $K$. septempunctata was detected in 29 samples (13.4\%) out of 216 sashimi, but not detected in sushi.

K. septempunctata was detected mainly in the summer, more specifically with 2 samples $(0.8 \%)$ in June, 25 samples $(10.6 \%)$ in July, and 2 samples $(0.8 \%)$ in August. Using the Chi-square analysis, we confirmed statistically that the $K$. septempunctata detection rates vary significantly from month to month $(p=0.000)$. Kim et al. (2018) also found that Kudoa-related food poisoning cases in 2015 and 2016 were the most common in April, followed by October and November in Gyeonggi Province, and were the highest in May and followed by August in Korea as a whole. Conversely, Song et al. (2013) reported that K. septempunctata is detected throughout the year from January to December. Therefore, further research is needed on the monthly infection trend of K. septempunctata.

By analyzing the results of the Real-time PCR screening, we found that the number of copies of Kudoa rDNA in 29 samples varies from $5 \times 10^{3}$ to $2.6 \times 10^{8}$ per $1 \mathrm{~g}$. By using the microscopy, we found K. septempunctata in 11 sashimi samples (Table 3 ). From the average value of the spores measured by four times in the hemocytometer, the number of the spores detected by $K$. septempunctata ranges from $1.0 \times 10^{4}$ to $9.0 \times 10^{5}$ spores per $1 \mathrm{~g}$, all of which were less than $10^{6}$ spores per $1 \mathrm{~g}$ of the standard for managing K. septempunctata in Japan.

\section{Kudoa nested PCR results}

We conducted the PCR test on eleven samples with K. septempunctata spores observed by comparing with the $18 \mathrm{~S} \mathrm{rDNA}$ and $28 \mathrm{~S} \mathrm{rDNA}$ of $K$. septempunctata, and found that the $18 \mathrm{~S} \mathrm{rDNA}$ target size is $333 \mathrm{bp}$ and the $28 \mathrm{~S}$ rDNA target size is $356 \mathrm{bp}$, which is a specific part of the K. septempunctata (Fig. 1). Among the eleven samples, five $(2.1 \%)$ samples were determined to be positive with K. septempunctata genes for nested PCR with both $18 \mathrm{~S}$ rDNA and $28 \mathrm{~S}$ rDNA. The distribution of olive flounders by original region is three from Jeju, one from Samcheonpo,

Table 2. The genotypes of Kudoa septempunctata

\begin{tabular}{llllll}
\hline Genotype & & Target gene & Accession no. & Target gene & Accession no. \\
\hline ST1 & Combined type of & cox1-1 & AB915831 & rnl-1 & AB915833 \\
ST2 & Combined type of & cox1-2 & AB915830 & rnl-2 & AB915832 \\
ST3 & Combined type of & cox1-3 & LC014799 & rnl-2 & AB915832 \\
\hline
\end{tabular}

${ }^{1)}$ The Genotype of K. septempuntata is determined by the combination of the cox 1 gene and rnl gene. 
Table 3. Quantification of Kudoa septempunctata by real-time PCR screening test and microscopic examination

\begin{tabular}{|c|c|c|c|c|c|c|c|}
\hline \multirow[t]{2}{*}{ Month } & \multirow[t]{2}{*}{$\begin{array}{l}\text { No. of samples } \\
\text { (no. of fish) }\end{array}$} & \multirow{2}{*}{$\begin{array}{l}\text { No. of } K \text {. septempunctata } \\
\text { detected samples by real-time } \\
\text { PCR (no. of fish) }\end{array}$} & \multicolumn{2}{|c|}{$\begin{array}{c}\text { Amounts by real-time PCR } \\
\text { (Kudoa rDNA copy/g) }\end{array}$} & \multirow{2}{*}{$\begin{array}{l}\text { No. of } K \text {. septempunctata detected } \\
\text { samples by microscopic exam- } \\
\text { ination (no. of fish) }\end{array}$} & \multicolumn{2}{|c|}{$\begin{array}{l}\text { Amounts by microscopic } \\
\text { examination (spore } / \mathrm{g} \text { ) }\end{array}$} \\
\hline & & & Min & Max & & Min & Max \\
\hline Jan & $2(1)$ & - & - & - & - & - & - \\
\hline Feb & $3(1)$ & - & - & - & - & - & - \\
\hline Mar & $6(2)$ & - & - & - & - & - & - \\
\hline Apr & $12(5)$ & - & - & - & - & - & - \\
\hline May & $14(8)$ & - & - & - & - & - & - \\
\hline Jun & $34(13)$ & $2(2)$ & $5.0 \times 10^{3}$ & $1.5 \times 10^{5}$ & - & - & - \\
\hline Jul & $41(22)$ & $25(13)$ & $6.3 \times 10^{3}$ & $2.6 \times 10^{8}$ & $11(6)$ & $1.0 \times 10^{4} / \mathrm{g}$ & $9.0 \times 10^{5} / \mathrm{g}$ \\
\hline Aug & $35(14)$ & $2(2)$ & $2.9 \times 10^{5}$ & $2.2 \times 10^{8}$ & - & - & - \\
\hline Sep & $38(10)$ & - & - & - & - & - & - \\
\hline Oct & $27(11)$ & - & - & - & - & - & - \\
\hline Nov & $20(15)$ & - & - & - & - & - & - \\
\hline Dec & $4(1)$ & - & - & - & - & - & - \\
\hline Total & $236(103)$ & $29(17)$ & $5.0 \times 10^{3}$ & $2.6 \times 10^{8}$ & $11(6)$ & $1.0 \times 10^{4} / \mathrm{g}$ & $9.0 \times 10^{5} / \mathrm{g}$ \\
\hline
\end{tabular}

(a)

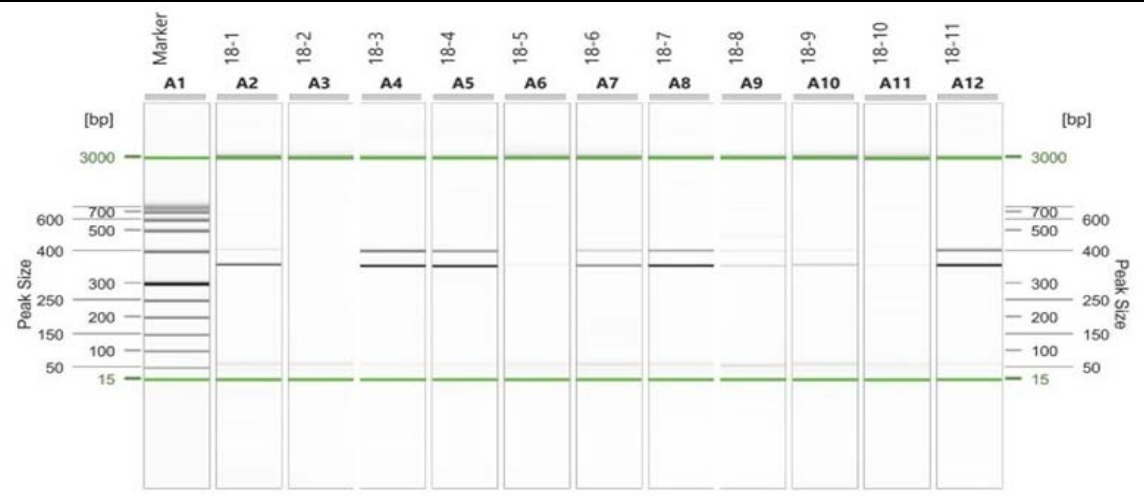

(b)

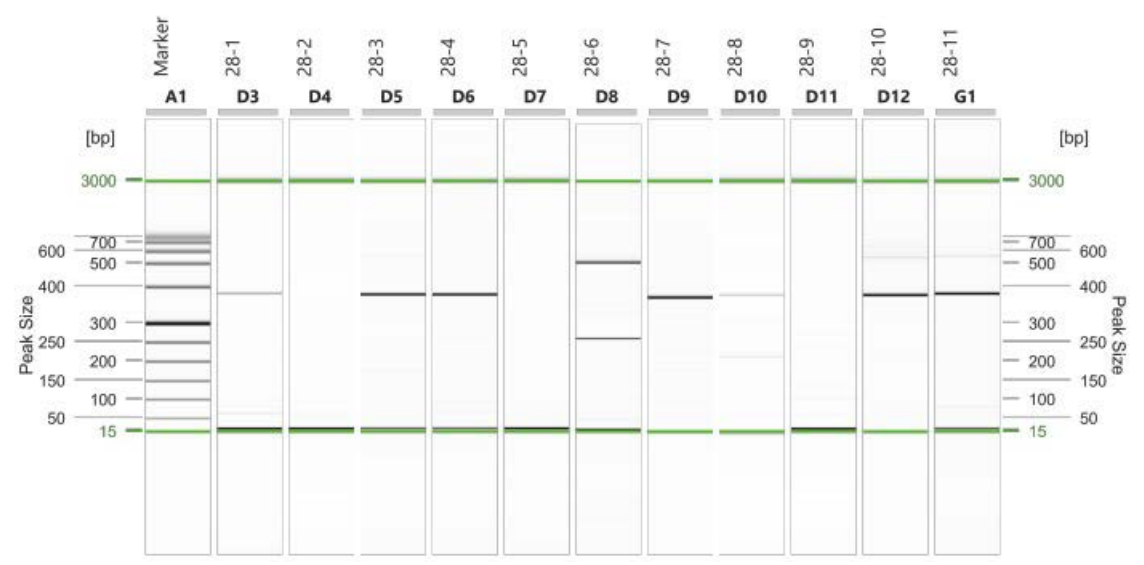

Fig. 1. 18S rDNA (a) and 28S rDNA (b) PCR results. The target size of $18 \mathrm{~S}$ rDNA is 333bp (a) and the target size of $28 \mathrm{~S}$ rDNA is 356 bp (b). The five samples $(1,3,4,7,11)$ are positive for both $18 \mathrm{~S}$ rDNA and $28 \mathrm{~S}$ rDNA target of Kudoa septempunctata. PCR, polymerase chain reaction. 
and one from Wando (Table 4).

Song et al. (2013) surveyed 270 adult flounders and flounder fries from 26 fish farms in Jeju in 2012, and reported that 4 samples (2.8\%) out of 143 adult flounders were detected with $K$. septempunctata genes. In addition, Song et al. (2014) collected 1,107 olive flounders from 89 fish farms in Jeju, Jeollanam-do, Gyeongnam, Gyeongbuk, and Gangwon-do, and reported that K. septempunctata genes were detected in 10 samples $(3.1 \%)$ out of the 318 olive flounders in Jeju, but were not detected in other regions. Kim et al. (2015) surveyed 660 olive flounders in 11 fish seeding farms on the southwest coast in Korea between 2014 and 2015, and K. septempunctata genes were not detected. In contrast to previous papers, $K$. septempunctata were detected in the sashimi which made of olive flounders from Samcheonpo and Wando in addition to olive flounders from Jeju. In this study, a completely new result was found with the previous papers that $K$. septempunctata were detected only in olive flounders on Jeju. Therefore, further monitoring is needed for sashimi and sushi with olive flounders from other domestic regions.

\section{Kudoa gene homogeneity and genotype analysis}

In order to evaluate the gene consistency of K. septempunctata of the detected samples with the standard strains, we compared the gene sequence with $18 \mathrm{~S}$ rDNA standard strains AB731754.1 and 28S rDNA standard strains AB731755.1. The five samples with $K$. septempunctata positive are identical from $98.4 \%$ to $100 \%$ consistent with the standard strains via NCBI Blast (https://www.ncbi.nlm.nih.gov/Blast) (Table 5).

The genotypes of $K$. septempunctata are ST1, ST2, and ST3, which are determined by combination of gene coxl (cytochrome coxidase subunit 1) and gene rnl (large subunit rRNA). Gene cox1 is divided into cox1-1, cox1-2, and cox1-3 due to the differences of six nucleotides, while gene rnl is divided into rnl1 and rnl-2 due to the differences of two nucleotides. By using Clustal W of the Bioedit program, we found that the gene sequences of $K$. septempunctata in the five samples are identical to ST3 with cox1-3 and rnl-2 (Fig. 2).

The genotypes of $K$. septempunctata vary depending on the country; ST1 and ST2 are mainly detected in Japan, while only ST3 is known to be detected in Korea (Takeuchi et al., 2015). In this study, the detected genotype of K. septempunctata is also

Table 4. The number of Kudoa septempunctata isolated from sashimi and sushi

\begin{tabular}{|c|c|c|c|c|}
\hline Food type & No. of samples & $\begin{array}{l}\text { No. of } K \text {. septempunctata detected by } \\
\text { microscopic examination }\end{array}$ & $\begin{array}{l}\text { No. of } K \text {. septempunctata detected by PCR test } \\
\text { with } 18 \mathrm{~S} \text { rDNA and } 28 \mathrm{~S} \text { rDNA }\end{array}$ & Region (no. of positive samples) \\
\hline Sashimi & 216 & 11 & 5 & Jeju (3), Samcheonpo (1), Wando (1) \\
\hline Sushi & 20 & 0 & 0 & - \\
\hline Total & 236 & $11(4.7 \%)$ & $5(2.1 \%)$ & \\
\hline
\end{tabular}

$\mathrm{PCR}$, polymerase chain reaction.

Table 5. Results by microscopic examination, PCR assays with Kudoa septempunctata in positive samples

\begin{tabular}{|c|c|c|c|c|c|c|}
\hline \multirow[t]{2}{*}{ Food type } & \multirow[t]{2}{*}{ Region } & \multirow[t]{2}{*}{ K. septempunctata spore } & \multicolumn{2}{|c|}{ K. septempunctata detected by PCR } & \multicolumn{2}{|c|}{ Identity of $K$. septempunctata } \\
\hline & & & 18S rDNA & $28 \mathrm{~S} r \mathrm{DNA}$ & AB731754.1 (\%) & AB731755.1 (\%) \\
\hline Sashimi-1 & Wando & $8.4 \times 10^{5} / \mathrm{g}$ & $\mathrm{P}$ & $P$ & 99.74 & 100 \\
\hline Sashimi-2 & Samcheonpo & $8.0 \times 10^{4} / \mathrm{g}$ & ND & ND & & \\
\hline Sashimi-3 & Samcheonpo & $9.0 \times 10^{5} / \mathrm{g}$ & $\mathrm{P}$ & $P$ & 99.48 & 99.72 \\
\hline Sashimi-4 & Jeju & $6.0 \times 10^{5} / \mathrm{g}$ & $\mathrm{P}$ & $P$ & 98.45 & 99.45 \\
\hline Sashimi-5 & Jeju & $2.0 \times 10^{4} / \mathrm{g}$ & ND & ND & & \\
\hline Sashimi-6 & Jeju & $1.8 \times 10^{5} / \mathrm{g}$ & ND & ND & & \\
\hline Sashimi-7 & Jeju & $5.0 \times 10^{5} / \mathrm{g}$ & $\mathrm{P}$ & $P$ & 98.43 & 100 \\
\hline Sashimi-8 & Jeju & $2.0 \times 10^{5} / \mathrm{g}$ & ND & ND & & \\
\hline Sashimi-9 & Jeju & $2.0 \times 10^{5} / \mathrm{g}$ & ND & ND & & \\
\hline Sashimi-10 & Jeju & $1.0 \times 10^{4} / \mathrm{g}$ & ND & ND & & \\
\hline Sashimi-11 & Jeju & $3.4 \times 10^{5} / \mathrm{g}$ & $\mathrm{P}$ & $P$ & 99.74 & 99.72 \\
\hline
\end{tabular}

$\mathrm{PCR}$, polymerase chain reaction; $\mathrm{P}$, positive; $\mathrm{ND}$, not detected. 
(a)

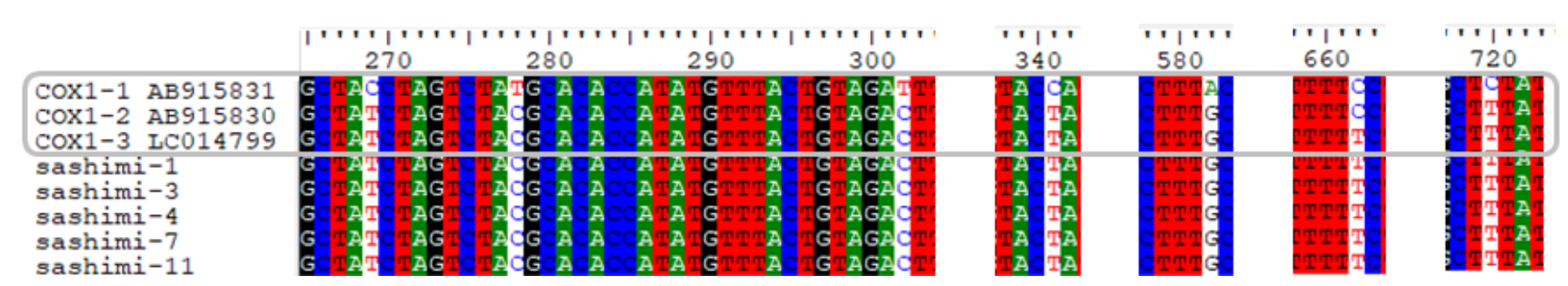

(b)

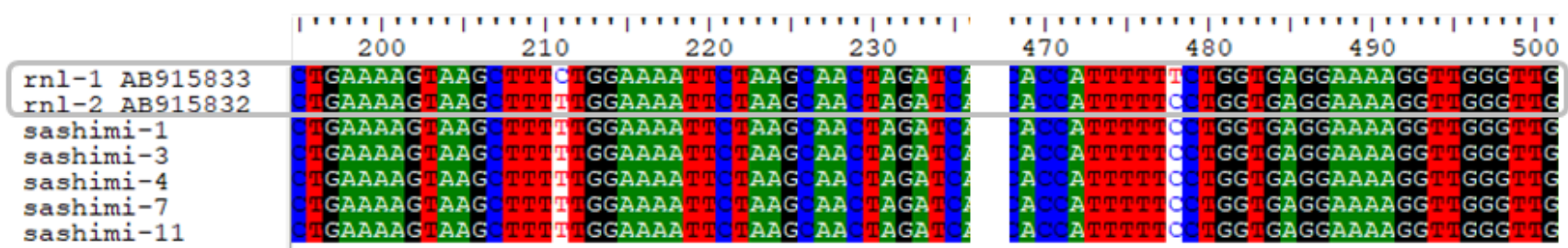

Fig. 2. The gene results of sequence analysis. The five samples are consistent with cox1-3 (a) and rnl-2 (b) on Kudoa septempunctata.

ST3, which is consistent with the results of the existing studies; Kim et al. (2018) reported all the genotypes of K. septempunctata detected in food poisoning patients in Gyeonggi-do Province were ST3. However, Jang et al. (2016) could not find any connection with the foodborne diseases in animal tests by eating olive flounders with $K$. septempunctata of ST3. Since the infection path of K. septempunctata and its connection with the intermediate host has not been identified, the additional studies are needed to identify it. Eventually, further studies are needed on the connection between sliced raw olive flounders and $\mathrm{Ku}$ doa food poisoning (Ahn et al., 2015).

In the experiments, we first performed the Real-time PCR to screen the olive flounder samples, and then check the Kudoa spores with the microscopy, and finally determine whether they are positive by the PCR test. This study detected 29 samples to be K. septempunctata positive in the Real-time PCR, and the microscopy confirmed 11 samples among 29 samples, and the PCR tests finally confirmed 5 samples as positive which are detected from both $18 \mathrm{~S}$ rDNA and $28 \mathrm{~S}$ rDNA target of $K$. septempunctata. The number of detected samples decreased as they went through the steps, because the Real-time PCR test had unusual reactions or very little DNA in some samples (Grabner et al., 2012). In the future, the Loop-mediated isothermal amplification method (LAMP) or more advances in the Real-time PCR method is needed on preventing Kudoa food poisoning or tracking the infection path (Jeon \& Kim, 2016; Kim et al., 2015; Song et al., 2014).
The previous researches only focused on the spread of $K$. septempunctata infections in olive flounders in fish farms, but no researches have been performed so far on the infection of K. septempunctata on sashimi and sushi in markets. In fact, the serious concern is that people have foodborne outbreaks from eating sashimi or sushi with $K$. septempunctata infected, so this study can be seen as the first step on preventing food poisoning. Now not only in Korea but also in the world, the detection criteria of K. septempunctata in sashimi and sushi have not been established yet, therefore we believe that the further research will be prioritized on the detection criteria for K. septempunctata in sashimi and sushi.

All the previous studies have detected K. septempunctata only in Jeju. However, this study found K. septempunctata in olive flounders sashimi from Samcheonpo and Wando other than Jeju. Within authors' knowledge, this is the first study to detect K. septempunctata outside of Jeju. It is necessary to continuously monitor whether the detection region of K. septempunctata widen depending on climate change and environmental factors.

\section{Competing interests}

No potential conflict of interest relevant to this article was reported.

\section{Funding sources}

Not applicable. 


\section{Acknowledgements}

Not applicable.

\section{Availability of data and materials}

Upon reasonable request, the datasets of this study can be available from the corresponding author.

\section{Ethics approval and consent to participate}

This article does not require IRB/IACUC approval because there are no human and animal participants.

\section{ORCID}

Hee-soo Koo Ji-young Park Gyung-hye Sung

Eun-hee Park

Pyeong-tae $\mathrm{Ku}$

Mi-ok Lee

\section{References}

Ahn M, Woo H, Kang B, Jang Y, Shin T. Effect of oral administration of Kudoa septempunctata genotype ST3 in adult BALB/c mice. Parasite. 2015;22:35.

Grabner DS, Yokoyama H, Shirakashi S, Kinami R. Diagnostic PCR assays to detect and differentiate Kudoa septempunctata, K. thyrsites and K. lateolabracis (Myxozoa, Multivalvulida) in muscle tissue of olive flounder (Paralichthys olivaceus). Aquaculture. 2012;338-341:36-40.

Harada T, Kawai T, Sato H, Yokoyama H, Kumeda Y. Development of a quantitative polymerase chain reaction assay for detection of Kudoa septempunctata in olive flounder (Paralichthys olivaceus). Int J Food Microbiol. 2012;156:161-7.

Jang Y, Ahn M, Bang H, Kang B. Effects of Kudoa septempunctata genotype ST3 isolate from Korea on ddY suckling mice. Parasite. 2016;23:18.

Jeon CH, Kim JH. Detection of Kudoa septempunctata (Myxozoa: Multivalvulida) in olive flounder (Paralichthys olivaceus) by DNA probe-based melting curve analysis. In: Proceedings of the 2016 KOFFST International Conference; 2016; Busan, Korea. p. 376.

Kawai T, Sekizuka T, Yahata Y, Kuroda M, Kumeda Y, Iijima Y, et al. Identification of Kudoa septempunctata as the causative agent of novel food poisoning outbreaks in Japan by consumption of Paralichthys olivaceus in raw fish. Clin In- fect Dis. 2012;54:1046-52.

Kim JJ, Ryu S, Lee H. Foodborne illness outbreaks in Gyeonggi province, Korea, following seafood consumption potentially caused by Kudoa septempunctata between 2015 and 2016. Osong Public Health Res Perspect. 2018;9:66-72.

Kim WS, Kong KH, Jung SJ, Jung MH, Jeon CH, Kim JH, et al. A survey of Kudoa septempunctata in olive flounder (Paralichthys olivaceus) hatcheries in the southwestern coast of Korea between 2014 and 2015. J Fish Pathol. 2015;28:10912.

Matsukane Y, Sato H, Tanaka S, Kamata Y, Sugita-Konishi Y. Kudoa septempunctata n. sp. (Myxosporea: Multivalvulida) from an aquacultured olive flounder (Paralichthys olivaceus) imported from Korea. Parasitol Res. 2010;107:865-72.

Ohnishi T, Kikuchi Y, Furusawa H, Kamata Y, Sugita-Konishi Y. Kudoa septempunctata invasion increases the permeability of human intestinal epithelial monolayer. Foodborne Pathog Dis. 2013;10:137-42.

Song JY, Choi JH, Choi HS, Jung SH, Park MA. Monitoring of Kudoa septempunctata in cultured olive flounder and wild fish in Jeju Island during 2012. J Fish Pathol. 2013;26:12937.

Song JY, Kim MJ, Choi HS, Jung SH. Monitoring Kudoa septempunctata in cultured olive flounder Paralichthys olivaceus in different regions of Korea in 2013. Korean J Fish Aquat Sci. $2014 ; 47: 611-21$.

Takeuchi F, Ogasawara Y, Kato K, Sekizuka T, Nozaki T, Sugita-Konishi Y, et al. Genetic variants of Kudoa septempunctata (Myxozoa: Multivalvulida), a flounder parasite causing foodborne disease. J Fish Dis. 2016;39:667-72. 